\title{
The first report of myeloma with IgD $\kappa$ and free $\kappa$ in Indonesia
}

\author{
Riadi Wirawan, ${ }^{1}$ Lidya Utami, ${ }^{2}$ Abdul Muthalib ${ }^{3}$ \\ ${ }^{1}$ Department of Clinical Pathology, Faculty of Medicine, Universitas Indonesia, Dr Cipto Mangunkusumo National Hospital, \\ Jakarta, Indonesia \\ ${ }^{2}$ Sentra Medika Cibinong Hospital, Bogor, Indonesia \\ ${ }^{3}$ Department of Internal Medicine, Faculty of Medicine, Universitas Indonesia, Dr Cipto Mangunkusumo National Hospital, \\ Jakarta
}

\begin{abstract}
Abstrak
Myeloma IgD к merupakan kasus keganasan sel plasma yang jarang dijumpai, dan belum pernah dilaporkan di Indonesia. Pada keadaan normal, kadar IgD dalam darah sangat rendah, sehingga peningkatan kadar IgD dalam darah dapat terlewatkan pada pemeriksaan elektroforesis protein serum. Pada makalah ini dilaporkan kasus seorang wanita 59 tahun dengan nyeri tulang hebat. Pemeriksaan radiologi menunjukkan adanya fraktur kompresi torakal dan penyempitan foramen torakal. Diagnosis mieloma pada pasien ini ditegakkan berdasarkan kriteria WHO, stadium berdasarkan kriteria Durie Salmon, dan prognosis buruk berdasarkan International Prognostic Index dari International Myeloma Working Group. Pada elektroforesis protein serum dijumpai spike monoklonal yang kecil dan pada imunofiksasi didapatkan IgD $\kappa$ and free light chain $\kappa$. (Med J Indones 2011; 20:217-21)
\end{abstract}

\begin{abstract}
IgD $\kappa$ myeloma is a rare plasma cell neoplasm case and has never been reported before in Indonesia. In normal condition, IgD level in blood is very low, therefore increase of $\mathrm{IgD}$ level in myeloma could be missed by serum protein electrophoresis. A case of a 59 years old female with severe bone pain is reported. In radiology evaluation, there were thoracal compression fracture and thoracal foramen narrowing. For this patient, the myeloma diagnosis was based on WHO criteria, the stage IIIb was based on Durie and Salmon criteria, and bad prognosis with prognostic index stage III diagnosis was based on International Prognostic Index from International Myeloma Working Group, respectively. In serum protein electrophoresis we found a very small monoclonal spike and in immunofixation there were monoclonal $\operatorname{IgD} \kappa$ and free light chain $\kappa$. (Med J Indones 2011; 20:217-21)
\end{abstract}

Key words: immunofixation, myeloma $\operatorname{Ig} D \kappa$, protein electrophoresis

Myeloma is a B cells malignancy which is characterized by monoclonal expansion and accumulation of abnormal plasma cells in the bone marrow, usually accompanied by monoclonal immunoglobulin secretion. The other typical findings in myeloma are bone lesion, anemia, hypercalcemia, and renal insufficiency. According to 2008 WHO classification of tumours, myeloma, which is also known as plasma cell myeloma, belongs to the group of plasma cell neoplasm, together with monoclonal gammopathy of undetermined significance (MGUS), plasmacytoma, immunoglobulin deposition disease, and osteosclerotic myeloma. ${ }^{1-4}$

Myeloma can evolve de novo or as a progression from MGUS and smoldering multiple myeloma. Proliferation of myeloma cells will lead to bone marrow infiltration and interaction with bone marrow microenvironment, which in turn induce the secretion of cytokines, such as interleukin 6 (IL-6), IL-1 $1 \beta$, IL11, tumor necrosis factor (TNF), transforming growth factor beta (TGF- $\beta$ ), dan receptor activator of nuclear factor kappa $\mathrm{B}$ ligand (RANKL). Those cytokines have important roles in proliferation and survival of myeloma cells, osteoclast activation, and osteoblast activity defect. Myeloma cells infiltration result in bone marrow failure, which shown as anemia, neutropenia, or thrombocytopenia, and bone destruction. Paraprotein produced by myeloma cells will lead to the increase of erythrocyte sedimentation rate, rouleaux formation in blood smear, increase of blood viscocity, coagulation defect, and neurological disorder. The paraprotein is detected in serum protein electrophoresis as spike in $\beta$ or $\gamma$ globulin area, in immunofixation as sharp band in conjuction with monoclonal immunoglobulin chain, and in urine as Bence Jones protein. Bone lesion will cause hypercalcemia, hypercalciuria, and the increase of serum ureum and creatinin due to renal function disorder. ${ }^{1,2}$

Myeloma represents $10 \%$ of blood cancer cases. It occurs in 5 every 100.000 people in the general population, with a higher prevalence rate in males compare to females, and median age of patients is 60 years old. Myeloma is more prevalent in black people. Types of myeloma includes IgG myeloma, typically $50 \%$, IgA myeloma, $25 \%$, light chain myeloma $24 \%$, IgD myeloma $1 \%$ of all cases, while IgE myeloma cases are rarely found. In $1 \%$ of the cases neither light 
or heavy chains are produced, called non secretory myeloma. ${ }^{4,5}$ A case of IgD myeloma has never been reported before in Indonesia.

\section{Case report}

A 59 years old female patient had been treated with complains of bone pains since 1 month before she was warded. Sharp pain is felt in the vertebrae, right chest and left leg, greater in intensity as time goes on. In the physical evaluation, it was discovered that the back and exteremitas are difficult to be moved.

Thoracal MRI evaluation found compression fractures at thoracal (Th) 5 dan Th 10, and neural foramen narrowing at Th 2-3 right, Th 3-4 right, Th 6-7 left, Th 10-11 right dan left, caused by metastasis. Lumbal MRI showed a diffuse change in the entire lumbal area, bone metastasis in the lumbosacral area was suspected.

Complete peripheral blood evaluation showed the following result : ESR: $145 \mathrm{~mm}(\mathrm{n}:<15), \mathrm{Hb}: 7.2 \mathrm{~g} / \mathrm{dL}$ (n : $12.0-14.0), \mathrm{Ht}: 23.3 \%$ ( $: 37.0-43.0)$, erythrocytes :

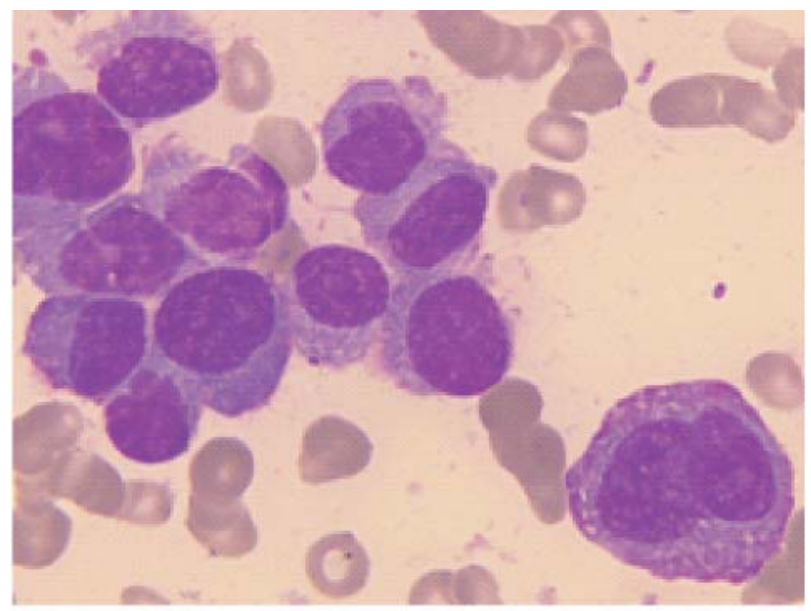

2.59 million/uL ( $\mathrm{n}: 4.00-5.00)$, leukocytes : 8,230/uL (n $: 5,000-10,000)$, thrombocytes : 70,000/uL (n : 150,000 $-400,000)$, and differential blood count : 2/1/2/60/31/4, with nucleated erythrocytes 2/100 leucocytes. Blood smear showed normocytic normochromic erythrocytes with rouleaux formation and nucleated red blood cell $2 / 100$ leucocytes. Leucocyte count is normal with basophilia and normal morphology. Thrombocyte count is less than normal with normal morphology.

Bone marrow evaluation showed hypercellular marrow with depression of thrombopoiesis, granulopoiesis and erythropoiesis. Plasmocyte count was found $63 \%$ of the nucleated cells in the bone marrow, with abnormal morphology: uneven side of cytoplasma, halo-less, unequal sizes, as well as double nuclei, as shown in Figure 1.

Protein electrophoresis evaluation found total protein $6,6 \mathrm{~g} / \mathrm{dL}$ (n : 6,6-8,7 g/dL), with decrease in albumin fraction, relative increase in $\alpha 1$ globulin, $\beta$ globulin, and $\gamma$ globulin fraction with a M spike in $\gamma$ globulin fraction, as shown Figure 2.

Figure 1. Various plasmocyte morphologies in bone marrow evaluation
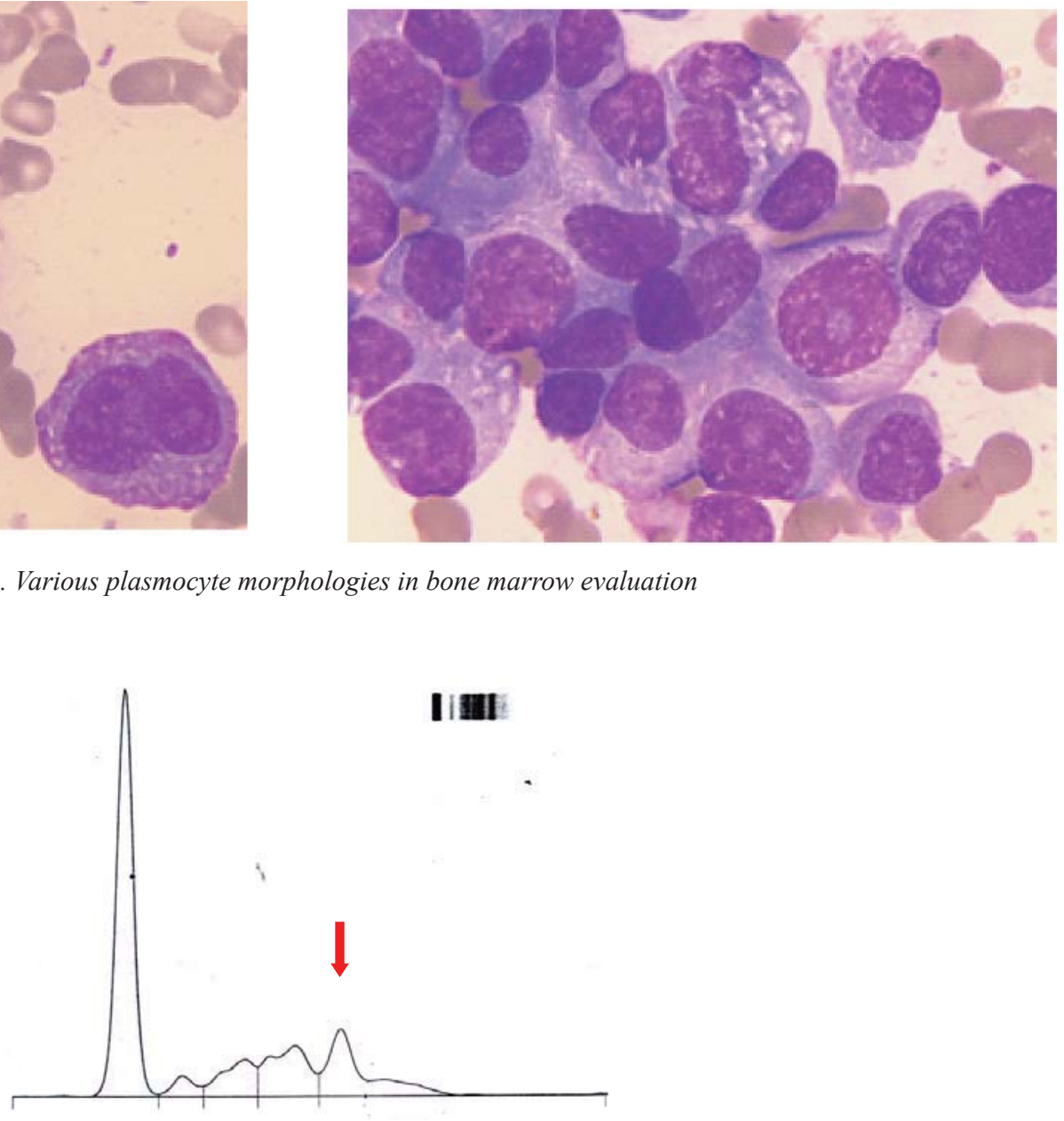

Figure 2. Serum protein electrophoresis 
Quantative immunoglobulin evaluation found a decrease in IgG level: $699 \mathrm{mg} / \mathrm{dL}$ ( $\mathrm{n}:$ 800-1813), $\operatorname{IgA}: 74 \mathrm{mg} / \mathrm{dL}$ ( $\mathrm{n}: 104-522)$, and $\operatorname{IgM}: 1 \mathrm{mg} / \mathrm{dL}$ (n : 52-217). Furthermore, it also found an increase in serum creatinine: $3,06 \mathrm{mg} / \mathrm{dL}(\mathrm{n}:<1,40)$, as well as serum calcium: $12,5 \mathrm{mg} / \mathrm{dL}(\mathrm{n}: 8,1-10,4)$, and $\beta 2$ microglobulin : $17.341 \mathrm{mg} / \mathrm{L}(\mathrm{n}: 0.670-1.310)$.

Serum immunofixation with anti $\mathrm{IgG}, \mathrm{A}, \mathrm{M}, \kappa$, dan $\lambda$ evaluation showed two monoclonal bands in $\kappa$. There were no monoclonal band in $\operatorname{IgG}$, IgA, or IgM. Urine immunofixation showed one monoclonal band $\kappa$ dan one monoclonal band in free $\kappa$. Further serum immunofixation with antibody against $\kappa, \lambda$, free $\kappa$ dan free $\lambda$ showed 2 monoclonal bands in $\kappa$ dan one monoclonal bands in free $\kappa$. Additional evaluation with anti $\operatorname{IgD}, \operatorname{IgE}, \kappa$, dan $\lambda$ showed one monoclonal band in $\operatorname{IgD}$ and two monoclonal bands in $\kappa$. Therefore, it can be concluded that the pasien has $\operatorname{IgD}$ monoclonal $\kappa$ with free light chain $\kappa$. The immunofixation result is show in Figure 3.
.Serum (1)

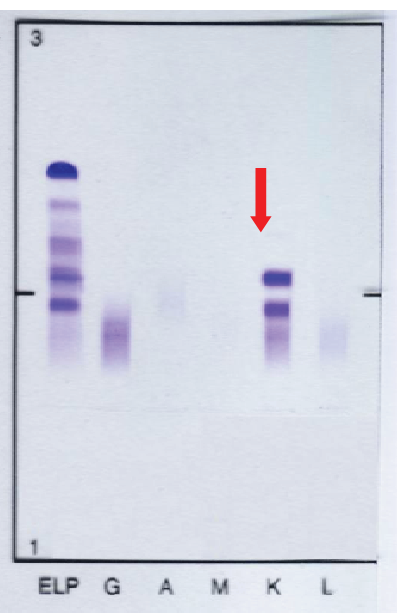

Serum (2)

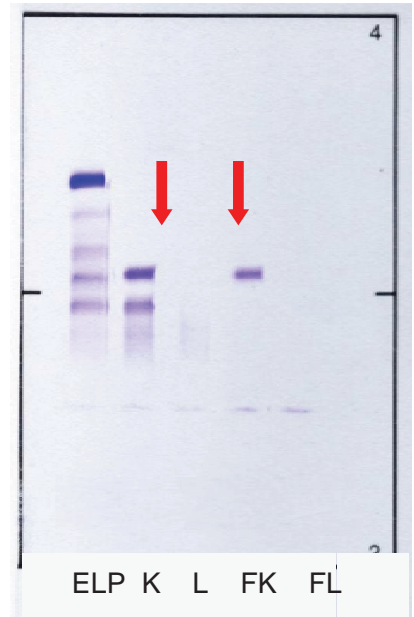

Serum (3)

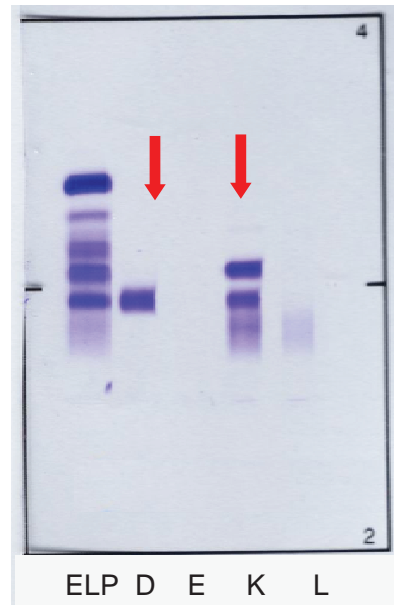

\section{Urine}

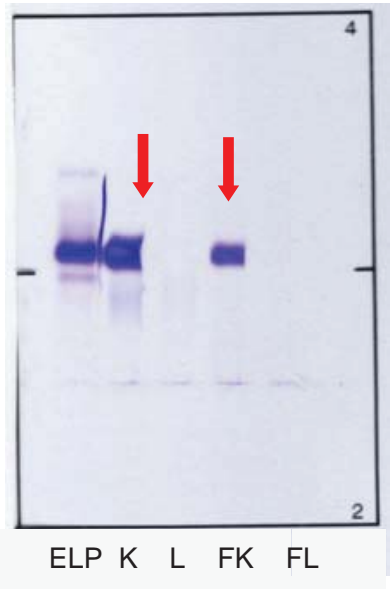

Figure 3. Serum and urin immunofixation results

\section{DISCUSSION}

The $\operatorname{IgD} \kappa$ and free $\kappa$ myeloma diagnosis in the patient was based on WHO criteria in 2008, which differentiate myeloma into two categories i.e. symptomatic myeloma and asymptomatic (smoldering) myeloma, as shown in Table I. ${ }^{4}$ The patient fulfilled the symptomatic myeloma criteria, i.e. M protein in both serum and urine, clonal plasma cells in the bone marrow, clonal plasmocytes were $63 \%$ among all marrow nucleated cells, and organ damage characterized with hypercalcemia, renal insufficiency, anemia, and bone lesions (CRAB).

Myeloma stage can be determined using the Durie and Salmon criteria, as shown in Table II. Based on the criteria, patient is in stage IIIB, due to her hemoglobin level $<8,5 \mathrm{~g} / \mathrm{dL}$, serum calcium $>12,0 \mathrm{mg} / \mathrm{dL}$ and serum creatinin $>2,0 \mathrm{mg} / \mathrm{dL}$.

Myeloma prognosis is based on the International Prognostic Index introduced by the International Myeloma Working Group. In this system, prognosis is determined by two parameters, $\beta 2$-microglobulin dan albumin, as shown in Table III. Prognosis in the patient is bad because of her high $\beta 2$-microglobulin level, placing her in stage 3 in the prognostic index.

IgD myeloma occurs $1-3 \%$ of myeloma cases, and most of them with $\lambda$ light chain. IgDк myeloma is found in 10$30 \%$ of $\operatorname{IgD}$ myeloma cases. Myeloma with monoclonal $\mathrm{IgD}$ usually shows a severe clinical characteristics and aggressive course, except in a patient reported by Tharp et al. ${ }^{4,7}$ Blade et $\mathrm{al}^{8}$ reported $53 \mathrm{IgD}$ myeloma found in Mayo clinic, USA, within 27 years (1965-1992). Lin et. al. ${ }^{9}$ in 2000 reported 16 patients treated in Chang Gung Memorial Hospital, Taiwan within 16 years (1982-1998), while Tan et $\mathrm{al}^{10}$ reported 4 patients in Singapore treated within 8 years (1990-1998). In Blade's et.al. ${ }^{8}$ report, clinical characteristics were bone pains $72 \%$, exhaustion $36 \%$, weight loss $32 \%$, extra medular plasmacytoma 19\%, and amyloidosis 19\%. Renal disorder and hypercalcemia were discovered in $33 \%$ and $22 \%$ patients, respectively. The M-spike in the serum protein electrophoresis was only found in $60 \%$ patients, while the remaining $40 \%$ has normal patterns or hipogamaglobulinemia. Bence Jones Proteinuria was found in $96 \%$ patients. $\lambda, \kappa$ and indeterminate light chains were discovered in $60 \%, 38 \%$ and $2 \%$ patients, respectively. Median survival is 21 months. 
Table 1. Myeloma diagnosis criteria according to $\mathrm{WHO}^{4}$

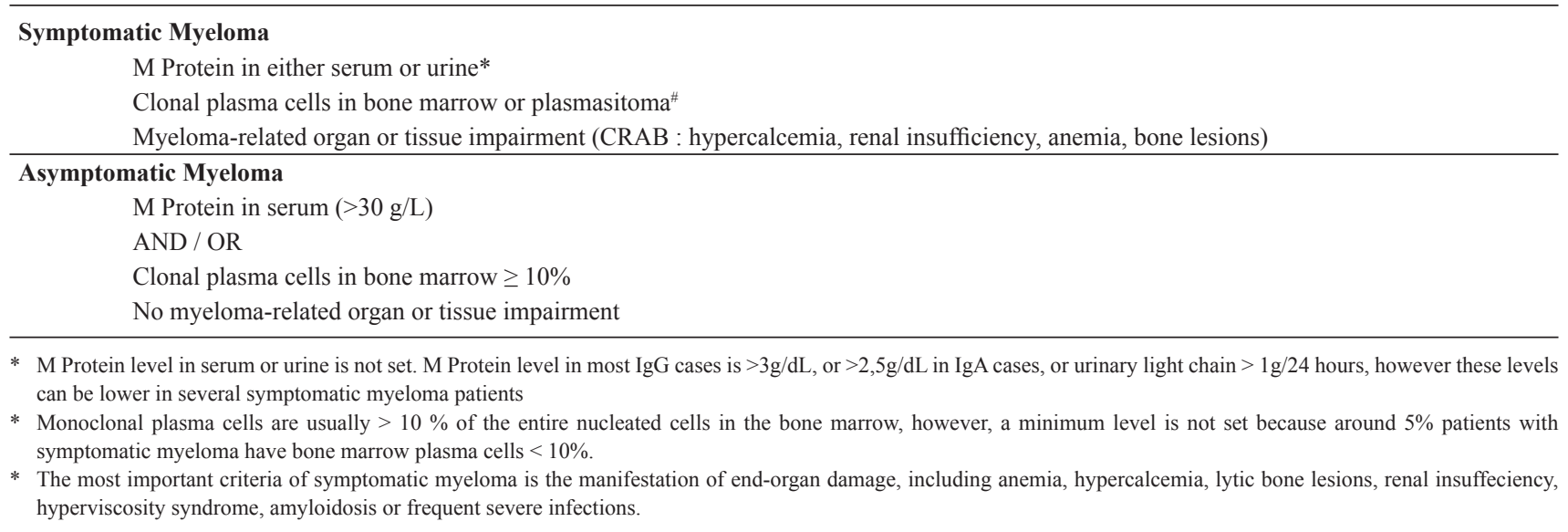

Table 2. Myeloma stages according to Durie and Salmon ${ }^{1,2}$

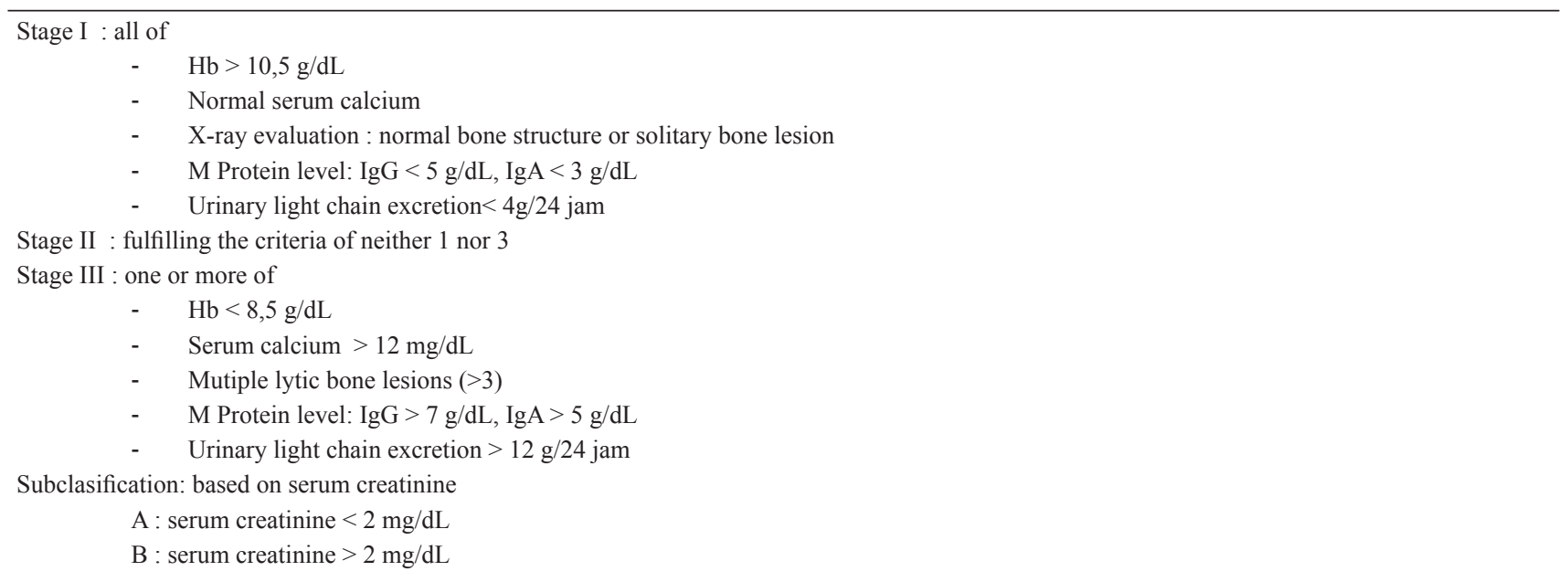

Table 3. International prognostic index mieloma ${ }^{1}$

Stage 1: $\beta 2$-microglobulin $<3,5 \mathrm{mg} / \mathrm{L}$, albumin $\geq 3,5 \mathrm{mg} / \mathrm{L}$

Stage 2 : $\beta 2$-microglobulin $<3,5 \mathrm{mg} / \mathrm{L}$, albumin $<3,5 \mathrm{mg} / \mathrm{L}$ atau $\beta 2$-microglobulin $3,5-5,5 \mathrm{mg} / \mathrm{L}$

Stage 3 : $\beta 2$-microglobulin $>5,5 \mathrm{mg} / \mathrm{L}$

Low risk : age $<60$ years old, $\beta 2$-microglobulin $<3,5 \mathrm{mg} / \mathrm{L}$, albumin $>3,5 \mathrm{~g} / \mathrm{dL}$

High risk : $\beta 2$-microglobulin $>10 \mathrm{mg} / \mathrm{L}$, albumin $<3,5 \mathrm{~g} / \mathrm{dL}$, low trombocyte count

Clinical characteristics of $\operatorname{IgD}$ myeloma reported by Lin et $\mathrm{al}^{9}$ were bone pains $56 \%$, gastrointestinal disorder $38 \%$, not feeling well $38 \%$ and weight loss $25 \%$. There were $75 \%$ patients with renal disorder and $63 \%$ patients with hypercalcemia, higher percentage compared to patients in USA. Cytopenia, hyperuricemia, increase in $\beta 2$-microglobulin level and Bence Jones Proteinuria were found in $88 \%, 69 \%, 86 \%$, and $92 \%$ of the patients. The M-spike in the serum protein electrophoresis only occured in 9 cases, while immunoelectrophoresis or immunofixation detected monoclonal gammopathy $\mathrm{IgD}$ in all the patients. Fifteen patients were in stage III. Median survival of IgD myeloma patients in Taiwan is 12 months, which is relatively short. All of $4 \mathrm{IgD}$ myeloma patients reported by Tan et $\mathrm{al}^{10}$ showed total protein within normal range. The monoclonal light chain consisted of $3 \lambda$ and $1 \kappa$.

In this case, we found intense bone pain, renal disorder, hypercalcemia, cytopenia, M-spike in the serum protein 
electrophoresis, elevated $\beta 2$-microglobulin and urinary light chain i.e. Bence Jones proteinuria, as reported by Lin et. al. ${ }^{9}$ In addition, extra medular plasmacytoma in the lumbosacral bone was found, as reported by Blade et. al. ${ }^{8}$

In several types of myeloma, such as $\mathrm{IgD}$ myeloma, $\operatorname{IgE}$ myeloma, light chain disease, and non secretory myeloma, serum protein electrophoresis often seems normal and does not show any sign of M-spike. At the moment, a novel free light chain and or $\kappa / \lambda$ ratio evaluation with nephelometry method is being developed. This evaluation can be utilized to help serum protein electrophoresis interpretation by identifying samples which requires immunofixation evaluation to detect small monoclonal band, which would be unclear or undetected otherwise. ${ }^{11}$

$\operatorname{IgD}$ and $\operatorname{IgE}$ levels in the blood are so low that $\operatorname{IgD}$ and IgE myeloma diagnosis are often hard to justify. If the quantitative immunoglobulin evaluation of myeloma suspected patients shows a decrease of $\operatorname{IgG}$, $\operatorname{IgA}$, or $\operatorname{IgM}$ levels then a possibility of $\operatorname{IgD}$ or $\operatorname{IgE}$ myeloma should be considered. If the immunofixation evaluation with antibody against $\operatorname{IgG}, \operatorname{Ig} \mathrm{A}, \operatorname{IgM}, \kappa$, and $\lambda$ does not show any monoclonal band on $\mathrm{G}, \mathrm{A}$ or $\mathrm{M}$ but shows one or more bands on $\kappa$ or $\lambda$ then additional immunofixation evaluation with anti $\kappa, \lambda$, free $\kappa$, free $\lambda$, and even anti $\operatorname{IgD}$ and anti $\operatorname{IgE}$ if required, needs to be done. If the protein electrophoresis does not show monoclonal characteristic, then the possibility of the myeloma suspected patient to be suffering from mieloma IgD, IgE, or non secretory myeloma should be considered. ${ }^{7}$ Free light chain level and or ratio evaluation needs to be carried out to prevent myeloma cases with no monoclonal characteristics in the serum protein electrophoresis from being undiagnosed. ${ }^{11}$

In conclusion, a 59 years old female patient was diagnosed with $\operatorname{IgD} \kappa$ myeloma according the WHO criteria, stage IIIB according to Durie dan Salmon criteria, and bad prognosis with prognostic index stage III according to the International Prognostic Index from International Myeloma Working Group. The protein electrophoresis evaluation showed a small M-spike and the immunofixation evaluation showed monoclonal bands in the igD $\kappa$ and free light chain $\kappa$. If the immunofixation evaluation of a myeloma suspected patient does not show $\mathrm{M}$ protein in $\operatorname{IgG}, \operatorname{IgA}$, IgM, but shows monoclonal band in the $\kappa$ or $\lambda$ in serum, additional immunofixation evaluation with anti $\operatorname{IgD}$, IgE, and light chain $\kappa$ or $\lambda$ needs to be performed.

\section{REFERENCES}

1. Terpos E, Rahemtulla A. Myeloma. In: Hoffbrand AV, Catovsky D, Tuddenham EGD, editors. Postgraduate haematology. $5^{\text {th }}$ ed. Massachusetts: Blackwell publishing Ltd; 2005. p. 681-702.

2. Dispenzieri A, Lacy MQ, Greipp PR. Multiple myeloma. In: Greer JP, Foerster J, Rodgers GM, Paraskevas F, Glader B, Arber DA, et al. Wintrobe's clinical hematology $12^{\text {th }}$ ed. Vol 2. Philadelphia : Lippincott Williams \& Wilkins; 2009. p.2372-438.

3. Munshi NC, Longo DL, Anderson KC. Plasma cell disorders. In : Fauci AS, Kasper DL, Longo DL, Braunwald E, Hauser SL, Jameson JL, et al, Harrison's principles of internal medicine $17^{\text {th }}$ ed vol 1. New York : McGraw Hills; 2008. p.700-7.

4. McKenna RW, Kyle RA, Kuehl WM, Grogan TM, Harris NL, Coupland RW. Plasma cell neoplasms. In: Swerdlow SH, Campo E, Harris NL, Jaffe ES, Pileri SA, Stein H, et al, editors. WHO classification of tumours of haematopoietic and lymphoid tissues $4^{\text {th }}$ ed. Lyon: International Agency for Research on Cancer. 2008: 200-13.

5. Datiles TB, Humphrey RL. Hypergammaglobulinemia. In: Sheehan C, editors. Clinical immunology, principles and laboratory diagnosis, $2^{\text {nd }}$ ed. Philadelphia: Lippincot; 1997. 317-29.

6. Kyle RA, Rajkumar SV. Criteria for diagnosis, staging, risk stratification and response assessment of multiple myeloma. Leukemia. 2009; $23: 3-9$.

7. Tharp AM, Woodruff RD, Shihabi ZK. Case report: IgDKappa Myeloma: an unusual case. Ann Clin Lab Sci. 2003; 33 (1) : 97-100.

8. Blade J, Lust JA, Kyle RA. Immunoglobulin D multiple myeloma presenting features, response to therapy, an survival in a series of 53 cases. J Clin Oncol. 1994;12:2398-404.

9. Lin TL, Shih LY, Dunn P, Wang PN, Wu JH, Kao MC. Immunoglobulin D multiple myeloma. Chang Gung Med J. 2000; 23(8):451-7.

10. Tan Lk, Suri R, Lim HL, Ong SK. Immunoglobulin D multiple myeloma in our hospital-a rare occurrence. Sing Med J. 2000; 41(10): 500-503.

11. Hill Pg. Forsyth JM, Rai B, Mayne S. Serum free light chains : an alternative to the urine Bence Jones proteins screening test for monoclonal gammopathies. Clin Chem. 2006; 59(2): 1743-8. 